Jurnal IImiah Potensia, 2019, Vol. 4 (2), 161-170

https://ejournal.unib.ac.id/index.php/potensia e-issn: 2621-2382 p-issn: 2527-9270

\title{
Pelaksanaan Kedisiplinan Guru PAUD Di Gugus Asoka
}

\author{
Rosa Karmelia ${ }^{1}$ \\ rochakarmelia10@gmail.com \\ Muhammad Nasirun² \\ h.m.nasirun@gmail.com \\ Indrawati ${ }^{3}$ \\ tindrawati61@gmail.com
}

1,2,3 Pendidikan Guru Pendidikan Anak Usia Dini, Universitas Bengkulu

Received: May $13^{\text {th }} 2019$

Accepted: July $28^{\text {th }} 2019$

Published: July $28^{\text {th }} 2019$

\begin{abstract}
Kedisiplinan merupakan sifat dari pertanggungjawaban individu untuk melaksanakan segala sesuatunya dengan tepat waktu. Jika tidak disiplin, maka pekerjaannya yang diembannya akan menjadi terbengkalai. Kedisiplinan juga perlu diterapkan dalam civitas akademika PAUD. Oleh karena itu tujuan dari penelitian ini adalah untuk mendeskripsikan pelaksanaan kedisiplinan Guru PAUD di Gugus Asoka Kecamatan Sungai Serut Kota Bengkulu. Metode penelitian adalah deskriptif kuantitatif. Populasi penelitian adalah semua guru di Gugus Asoka Kecamatan Sungai Serut Kota Bengkulu. Sampel populasi yang ada di Gugus Asoka Kecamatan Sungai Serut Kota Bengkulu berjumlah 30 orang guru dengan teknik total sampling. Teknik pengumpulan data menggunakan observasi. Teknik analisis menggunakan uji statistik rata-rata. Hasil penelitian menunjukkan bahwa pelaksanaan kedisiplinan guru PAUD ada pada kategori baik. Pada kedisiplinan guru sikap dan tingkah laku ada pada kategori cukup. Berdasarkan hasil penelitian tersebut disarankan agar kedisiplinan guru dapat lebih ditingkatkan lagi terutama pada kedisiplinan sikap dan tingkah laku agar kedisiplinan guru untuk kedepannya dapat lebih baik lagi.
\end{abstract}

Keywords Kedisiplinan Guru PAUD

How to cite this article:

Karmelia, R., Nasirun, M., \& Indrawati, I. (2019). Pelaksanaan Kedisiplinan Guru PAUD Di Gugus Asoka. Jurnal Ilmiah POTENSIA, 4(2), 161-170. doi:https://doi.org/10.33369/jip.4.2.161-170

\section{PENDAHULUAN}

Menurut Undang-Undang No. 20 tahun 2003 Bab 1 Pasal 1 Ayat 14 Pendidikan Anak Usia Dini adalah suatu upaya pembinaan yang ditunjukkan kepada anak sejak lahir sampai dengan usia enam tahun yang dilakukan melalui pemberian rangsangan pendidikan untuk membantu pertumbuhan dan perkembangan jasmani dan rohani agar anak memiliki kesiapan dalam memasuki pendidikan lebih lanjut.
Mansur (2007: 88) menjelaskan bahwa pendidikan Anak Usia Dini adalah suatu proses pembinaan tumbuh kembang anak lahir hingga enam tahun secara menyeluruh yang mencakup aspek fisik dan nonfisik dengan memberikan rangsangan bagi perkembangan jasmani, rohani, (moral dan spiritual), motorik, akal pikiran, emosional dan sosial yang tepat agar anak tumbuh dan berkembang secara optimal. 
Sedangkan Sujiono (2011:7) menyatakan bahwa Pendidikan Anak Usia Dini pada dasarnya meliputi seluruh upaya dan tindakan oleh pendidik dan orang tua dalam proses perawatan, pengasuhan, dan pendidikan pada anak dengan menciptakan aura dan lingkungan dimana anak dapat mengeksplorasi pengalaman yang memberikan kesempatan kepadanya untuk mengetahui dan memahami pengalaman belajar yang diperolehnya dari lingkungan, melalui cara mengamati, meniru dan bereksperimen yang berlangsung secara berulang-ulang dan melibatkan seluruh potensi dan kecerdasan anak. Pendidikan anak usia dini merupakan awal anak dalam mengenal lingkungan dan menirukan semua yang ia lihat.

Sebagaimana dalam pasal 3 angka 11 Peraturan Pemerintah No. 53 Tahun 2010 tentang Disiplin Pegawai Negeri Sipil yang mewajibkan PNS masuk kerja dan mentaati ketentuan jam kerja. Dalam pasal tersebut dijelaskan bahwa yang dimaksud dengan kewajiban untuk "masuk kerja dan mentaati ketentuan jam kerja" adalah setiap PNS wajib datang, melaksanakan tugas, dan pulang sesuai ketentuan jam kerja serta tidak berada ditempat umum bukan karena dinas. Apabila berhalangan hadir wajib memberitahu kepada pejabat yang berwenang. Keterlambatan masuk kerja dan atau pulang cepat dihitung secara kumulatif dan dikonvei 7,5 jam sama dengan satu hari tidak masuk kerja.

Mulyasa (2009: 122) memberikan penjelasan bahwa dalam pendidikan, mendisiplinkan anak harus dimulai dari pribadi guru yang disiplin, kita tidak bisa berharap banyak akan terbentuknya anak yang disiplin dari pribadi yang kurang disiplin. Oleh karena itu membina disiplin anak usia dini harus dimulai dari pribadi guru yang disiplin. Semakin baik disiplin guru maka memberikan pengaruh terhadap disiplin anak didiknya
Dalam Undang-Undamg Nomor 14 Tahun 2005 tentang Guru dan Dosen, disebutkan bahwa Guru adalah pendidik profesional yang memilki tugas utama mendidik, mengajar, membimbing, mengarahkan, melatih, menilai dan mengevaluasi peserta didik pada pendidikan anak usia dini jalur pendidikan formal, pendidikan dasar dan pendidikan menengah. Guru merupakan sosok yang memiliki kedudukan penting bagi perkembangan potensi siswa. Hal ini disebabkan guru menjadi komponen yang paling berpengaruh pada terciptanya proses dan hasil pendidikan yang berkualitas. Berhasil atau tidaknya suatu pendidikan dalam mencapai tujuan akan selalu dikaitkan dengan kinerja guru menurut (Anggraini, 2017: 8).

Menurut Sastrohadiwiryo (2002: 90) bahwa disiplin kerja didefinisikan sabagai suatu sikap menghormati, menghargai, patuh, dan taat terhadap peraturanperaturan yang berlaku baik yang tertulis maupun tidak tertulis serta sanggup menjalankannya dan tidak mengelak untuk menerima sanksi-sanksinya apabila ia melanggar tugas dan wewenang yang diberikan kepadanya. Faktor pendukung dominan bagi kedisiplinan guru berasal dari dalam diri guru sendiri. Faktor-faktor tersebut yaitu kompetensi profesional, motivasi, kreativitas, dan produktivitas guru, pendidikan, serta karakter guru. Bagi guru yang berdisiplin, karena sudah menyatu dalam dirinya, maka disiplin bukan lagi merupakan beban, namun sebaliknya membebani dirinya bila tidak berbuat disiplin. Nilai-nilai kepatuhan telah menjadi bagian dari perilaku kesehariannya, menurut (Yoesana, 2013:14).

Mulyasa (2013: 188) menyatakan bahwa berdisiplin mengandung makna bahwa guru menyadari, memahami dan mematuhi berbagai peraturan dan tata tertib secara konsisten dan professional karena mereka bertugas untuk 
mendisiplinkan para peserta didiknya, oleh karenanya dalam menanamkan disiplin guru harus memulai dari dirinya sendiri dalam berbagai tindakan dan perilakunya.

Berdasarkan pengamatan yang dilakukan oleh peneliti di PAUD gugus Asoka, menunjukkan bahwa masih ada anak yang belum mematuhi tata tertib sekolah, sebagai contoh pada saat upacara anak tidak membawa topi, tidak menggunakan dasi, berpakaian tidak lengkap ataupun tidak menggunakan sepatunya. Ketika jam masuk kelas masih ada anak yang keluar masuk kelas, atau berkeliaran di sekitaran kelas. Masih ada anak yang datang tidak tepat waktu ke sekolah.

Tujuan dari penelitian ini adalah untuk mendeskripsikan pelaksanaan kedisiplinan guru PAUD di Gugus Asoka Kecamatan Sungai Serut Kota Bengkulu

Disiplin berasal dari kata "disciple" yakni seseorang yang belajar secara suka rela mengikuti seorang pemimpin. Menurut Mulyasa (2005: 37) mendefinisikan disiplin adalah mematuhi berbagai peraturan dan tata tertib secara konsisten

Menurut Hasibuan (2009: 193) Disiplin berasal dari kata inggris yakni "discipline" yang berarti: tertib, taat atau mengendalikan tingkah laku, penguasaan diri, kendali diri, latihan membentuk, meluruskan, atau menyempurnakan sesuatu, sebagai kemampuan mental atau karakter moral, hukum yang diberikan untuk melatih atau memperbaiki kumpulan atau sistem peraturan-peraturan bagi tingkah laku.

Disebutkan dalam Undang-undang No 14 Tahun 2005 Tentang Guru dan Dosen Pasal 1 disebutkan bahwa guru adalah pendidik profesional dengan tugas utama mendidik, mengajar, membimbing, mengarahkan, melatih, menilai dan mengevaluasi peserta didik pada pendidikan anak usia dini jalur formal, pendidikan dasar dan pendidikan menengah.
Secara umum menurut Daradjat (2006: 39) guru dapat diartikan sebagai pendidikan professional. Ketika orangtua menyerahkan anaknya disekolah, artinya sebagian tanggung jawab pendidikan anak dilaksanakan oleh guru. Hal itu menunjukkan bahwa orangtua tidak mungkin mempercayai anaknya kesembarang guru, karena tidak semua orang bisa dapat mejabat sebagai seorang guru.

Secara khusus menurut Nawawi dalam Kurniawan (2016: 51) mengatakan bahwa guru adalah orang yang bekerja dalam bidang pendidikan dan pengajaran yang ikut bertanggung jawab dalam membantu anak-anak mencapai kedewasaan masing-masing. Guru dalam pengertian tersebut dengan demikian bukanlah sekedar orang yang berdiri di depan kelas untuk menyampaikan materi, melainkan seseorang yang memiliki karakter dan kepribadian dalam membantu anak mencapai kedewasaan berperilaku.

Menurut Imron (2011: 172) kedisiplin guru adalah suatu keadaan tertib dan teratur yang dimiliki guru dalam bekerja di sekolah, tanpa ada pelanggaranpelanggaran yang merugikan baik secara langsung maupun secara tidak langsung terhadap diri sendiri, teman sejawat dan terhadap sekolah secara keseluruhan.

Menurut Rahman (2013: 66-68) bahwa penerapan disiplin memilki beberapa konsep: 1) Konsep disiplin otoriter, 2) Konsep disiplin permisif, 3) Konsep disiplin demokratis

Menurut Tu'u (2004: 18) fungsi kedisiplinan sebagai berikut: 1) Menata kehidupan bersama, 2) Membangun kepribadian, 3) Melatih kepribadian, 4) Pemaksaan, 5) Hukuman, 6) Lingkungan kondusif Menurut Unaradjan (2003: 27-32) terbentuknya disiplin diri sebagai tingkah laku yang berpola dan teratur dipengaruhi oleh dua faktor antara lain:1) Faktor-faktor ekstern, yang dimaksud dalam hal ini adalah 
unsur-unsur yang berasal dari luar pribadi yang dibina. Faktor-faktor tersebut yaitu: Keadaan keluarga, Keadaan lingkungan sekolah, Keadaan masyarakat. 2) Faktorfaktor intern, yaitu unsur-unsur yang berasal dari dalam diri individu. Yang dalam hal ini keadaan fisik dan psikis pribadi tersebut mempengaruhi unsur pembentukan disiplin dalam diri individu: Keadaan fisik, Keadaan psikis.

Menurut Idris dan Sandra (2010: 131) Guru yang memiliki kedisiplinan adalah guru yang memiliki indikator sebagai berikut:1) Disiplin dalam melaksanakan tugas tata tertib dengan baik, 2) Disiplin dalam melayani peserta didik, 3) Disiplin terhadap suasana kerja, 4) Disiplin waktu, 5) Disiplin dalam sikap dan tingkah laku

Menurut Jannah (2013: 91-93) bahwa sikap disiplin mengandung banyak arti. Dalam istilah bahasa inggris, dikenal dengan istilah discipline, yang di antaranya terangkum dalam beberapa manfaat. Berikut manfaat tersebut: 1) Pengendalian diri, 2) Membentuk karakter bermoral, 3) Memperbaiki dengan sanksi, 4) Kumpulan tata tertib

\section{METODE PENELITIAN}

\section{Rancangan Penelitian}

Menurut Sugiyono (2011: 3) metode penelitian merupakan cara ilmiah untuk mendapatkan data dengan tujuan dan kegunaan tertentu. Metode yang digunakan dalam penelitian ini adalah metode penelitian deskriptif kuantitatif.

Peneliti menggunakan metode deskriptif kuantitatif karena peneliti akan mendeskripsikan secara faktual dan akurat terhadap pelaksanaan kedisiplinan guru PAUD gugus Asoka Kecamatan Sungai Serut Kota Bengkulu. Untuk mendapatkan data peneliti menggunakan Lembar Observasi kepada kepala sekolah yang ada di gugus Asoka dengan cara menggunakan pernyataan terstruktur atau sistematis. Kemudian seluruh jawaban yang diperoleh akan dicatat, diolah dan dianalisis dengan menggunakan angka.

\section{Populasi dan sampel}

Menurut Sugiyono (2010: 117) adalah wilayah generalasasi yang terdiri atas objek/subjek yang mempunyai kualitas dan karakteristik tertentu yang diterapkan oleh peneliti untuk dipelajari kemudian ditarik kesimpulan.

Tabel 1. Jumlah Guru PAUD di Gugus Asoka Kecamatan SIngaran Pati Kota Bengkulu

\begin{tabular}{lll}
\hline No & Nama Sekolah & $\begin{array}{l}\text { Jumlah } \\
\text { Guru }\end{array}$ \\
\hline 1 & PAUD IT Luqmanul Hakim & 7 guru \\
\hline 2 & PAUD Abdan Sakura & 5 guru \\
\hline 3 & PAUD Delima & 5 guru \\
\hline 4 & PAUD Karya Bakti & 2 guru \\
\hline 5 & PAUD Twi Dini & 3 guru \\
\hline 6 & PAUD Sopo Indah & 3 guru \\
\hline 7 & PAUD IT AL Khanza & 3 guru \\
\hline 8 & PAUD Angkasawan & 2 guru \\
\hline Jumlah & 30 guru \\
\hline
\end{tabular}

Menurut Arikunto (2006: 131) jika hanya akan meneliti sebagian dari populasi, maka penelitian disebut penelitian sampel. Sampel adalah sebagian atau wakil populasi yang diteliti. Dinamakan penelitian sampel apabila kita bermaksud untuk menggeneralisasikan hasil penelitian sampel. Menggeneralisasikan adalah mengangkat kesimpulan penelitian sebagai suatu yang berlaku bagi populasi.

Menurut Arikunto apabila populasi kurang dari 100 sebaiknya menggunakan sampel total. Dalam penelitian ini digunakan sampel dari semua populasi karena kurang dari 100 (total sampling). Pada penelitian ini sampel yang digunakan adalah semua guru yang berada di PAUD Gugus Asoka Kecamatan Sungai Serut Kota Bengkulu. 
Jurnal IImiah Potensia, 2019, Vol. 4 (2), 161-170

https://ejournal.unib.ac.id/index.php/potensia

e-issn: 2621-2382 p-issn: 2527-9270

Tabel 2. Jumlah Sampel Guru PAUD

\begin{tabular}{lll}
\hline No & Jenis Kelamin Guru & $\begin{array}{l}\text { Jumlah } \\
\text { anak }\end{array}$ \\
\hline 1 & Perempuan & 30 Guru \\
\hline & Jumlah & 30 Guru \\
\hline
\end{tabular}

\section{Teknik Pengumpulan Data}

Menurut Arikunto (2006: 229) observasi adalah teknik pengumpulan data yang bukan sekedar mencatat, tetapi juga mengadakan pertimbangan kemudian mengadakan penilaian ke dalam suatu skala bertingkat.

Dalam penelitian ini menggunakan skala Gutman. Menurut Sugiyono (2009: 111) skala pengkuran dengan tipe ini akan di dapat jawaban yang tegas yaitu "yatidak", "benar-salah", pernah-tidak pernah, "positif-negatif" dan lain-lain.

Penelitian dengan menggunakan skala Gutman dilakukan bila ingin mendapatkan jawaban yang tegas terhadap suatu permasalahan yang ditanyakan. Skala Gutman selain dapat dibuat dalam bentuk checklist. Jawaban dapat juga dibuat skor tertinggi 1 dan terendah 0 . Misal dengan jawaban yang diberi jawaban 1 dan tidak diberi skor 0 . Analisa dilakukan seperti pada skala likert.

\section{Teknik Analisis Data}

Menurut Sugiyono (2010: 243) teknik analisis data adalah cara yang digunakan peneliti dengan tujuan untuk menafsirkan atau memberi makna terhadap data yang telah dikumpulkan.

Teknik analisis data yang digunakan peneliti dalam penelitian ini di ambil dari hasil lembar observasi yang dilakukan peneliti pada saat meneliti.

Teknik analisis data yang digunakan dalam penelitian ini adalah

$$
\bar{X}=\frac{\sum n}{n}
$$

keterangan :

$\bar{X} \quad$ : nilai rata-rata

$\sum n$ : jumlah semua nilai guru

$\mathrm{n} \quad$ : jumlah guru

\section{HASIL DAN PEMBAHASAN \\ Hasil}

Penelitian deskriptif kuantitatif ini dilakukan pada guru PAUD di Gugus Asoka Kecamatan Sungai Serut Kota Bengkulu. Penelitian ini bertujuan untuk mendeskripsikan pelaksanaan kedisiplinan guru PAUD di Gugus Asoka Kecamatan Sungai Serut Kota Bengkulu.

Pengambilan data dalam penelitian ini dilakukan dengan cara memberikan lembar observasi yang diisi oleh kepala sekolah terhadap guru PAUD di setiap lembaga yang ada di Gugus Asoka Kecamatan Sungai Serut Kota Bengkulu. Lembar observasi yang diisi oleh kepala sekolah terdiri dari 5 indikator dan 35 item pernyataan. Berdasarkan hasil penelitian yang dilakukan di Gugus Asoka Kecamatan Sungai Serut Kota Bengkulu, tentang pelaksanaan kedisiplinan guru PAUD di Gugus Asoka Kecamatan Sungai Serut Kota Bengkulu.

Berdasarkan 5 indikator kedisiplinan guru PAUD maka total rata-rata yang diperoleh adalah 4.5 dengan kriteria baik masih ada kedisiplinan guru PAUD yang belum secara utuh digunakan dengan baik, rata-rata paling tinggi 5 diperoleh pada kedisiplinan suasana kerja dan kedisiplinan waktu, dan nilai rata-rata paling rendah 3.2 diperoleh pada kedisiplinan dalam sikap dan tingkah laku. Adapun hasil yang diperoleh sebagai berikut:

\section{a. Kedisiplinan Dalam Melaksanakan Tugas Tata Tertib Dengan Baik \\ Pada kedisiplinan dalam} melaksanakan tugas tata tertib dengan baik rata-rata nilai yang diperoleh semua guru adalah 4,9 dengan kriteria sangat baik dimana pada kedisiplinan dalam 
melaksanakan tugas tata tertib nilai ratarata paling tinggi 5,0 diperoleh hampir kesemua guru dengan kriteria sangat baik dengan skor yang diperoleh adalah 5, sedangkan nilai rata-rata paling sedang 4,0 diperoleh guru MD.

Berdasarkan pada kedisiplinan dalam melaksanakan tugas tata dengan baik ratarata hasil yang diperoleh semua guru pada lembar observasi adalah 4,9 dari keseluruhan skor yang diterima dengan kriteria sangat baik dimaksudkan rata-rata kedisiplinan guru sudah melaksanakan dengan baik namun ada beberapa item pernyataan yang belum berjalan dengan baik seperti pada item pernyataan nomor 7 dimana item pernyataan tersebut belum terlaksana dengan baik.

Di mana setiap guru pada observasi yang dilakukan sudah melakukan kedisiplinan dalam tugas tata tertib dengan baik terlihat saat jam masuk dimulai guru mengisi absensi siswa sebelum proses pembelajaran dimulai, menyiapkan $\mathrm{RPPH}$ dan media pembelajaran yang akan digunakan, kemudian memberi tahu sekolah jika tidak bisa hadir dan guru juga mendapingi siswa dalam setiap kegiatan sekolah yang dilaksanakan.

\section{b. Kedisiplinan Dalam Melayani Peserta Didik}

Pada kedisiplinan dalam melayani peserta didik nilai rata-rata yang diperoleh semua guru adalah 4,7 dengan kriteria sangat baik di mana pada kedisiplinan dalam melayani peserta didik nilai rata-rata paling tinggi 5,0 diperoleh 21 guru dengan kriteria sangat baik pada lembar observasi skor yang diperoleh adalah 5 , sedangkan nilai rata-rata sedang 4,0 diperoleh 9 guru dengan kriteria baik skor yang diperoleh adalah 4.

Berdasarkan pada kedisiplinan dalam melayani peserta didik rata-rata hasil yang diperoleh semua guru pada lembar observasi adalah 4,7 dari keseluruhan skor yang diterima dengan kriteria sangat baik dimaksudkan rata-rata kedisiplinan guru sudah melaksanakan dengan baik namun ada beberapa item pernyataan yang belum berjalan dengan baik seperti pada item pernyataan nomor 10 dan 13 dimana item pernyataan tersebut belum terlaksana dengan baik.

Di mana setiap guru pada observasi yang dilakukan sudah melakukan kedisiplinan dalam melayani peserta didik dengan baik hanya saja saat telibat dalam kegiatan sekolah guru masih proaktif dalam melakukannya pada saat kegiatan pagi masih ada guru yang asik dengan kegiatannya masing-masing, hendaknya guru langsung berinsiatif memperhatikan anak-anaknya dalam kegiatan pagi, pada saat anak terlambat datang sekolah hendaknya guru memberikan hukuman nasehat yang baik untuk peserta didiknya agar tidak terlambat lagi.

\section{c. Kedisiplinan Terhadap Susana Kerja}

Pada kedisiplinan terhadap suasana kerja nilai rata-rata yang diperoleh semua guru adalah 5,0 dengan kriteria sangan baik di mana pada kedisiplinan terhadap suasana kerja nilai rata-rata paling tinggi 5,0 diperoleh kesemua guru dengan kriteria sangat baik pada lembar observasi skor yang diperoleh adalah 5 .

Berdasarkan pada kedisiplinan suasana kerja rata-rata hasil yang diperoleh semua guru pada lembar observasi adalah 5,0 dari keseluruhan skor yang diterima dengan kriteria sangat baik dimaksudkan rata-rata kedisiplinan guru sudah melaksanakan dengan baik sehingga tidak ada yang tidak pada item pernyataan yang belum berjalan dengan baik semua terlaksana dengan baik.

Di mana setiap guru pada observasi yang dilakukan sudah melakukan kedisiplinan suasana kerja dengan baik seperti saat di sekolah maupun diluar sekolah guru menjaga nama baik sekolah, dari guru yang memiliki motivasi yang tinggi 
dalam dirinya dapat meningkat kinerja sekolah

\section{d. Kedisiplinan Waktu}

Pada kedisiplinan waktu nilai rata-rata yang diperoleh semua guru adalah 5,0 dengan kriteria sangan baik di mana pada kedisiplinan terhadap suasana kerja nilai rata-rata paling tinggi 5,0 diperoleh kesemua guru dengan kriteria sangat baik pada lembar observasi skor yang diperoleh adalah 5 .

Berdasarkan pada kedisiplinan waktu rata-rata hasil yang diperoleh semua guru pada lembar observasi adalah 5,0 dari keseluruhan skor yang diterima dengan kriteria sangat baik dimaksudkan rata-rata kedisiplinan guru sudah melaksanakan dengan baik sehingga tidak ada yang tidak pada item pernyataan yang belum berjalan dengan baik semua terlaksana dengan baik.

Di mana setiap guru pada observasi yang dilakukan sudah melakukan kedisiplinan waktu dengan baik seperti guru mematuhi peraturan yang ada di sekolah dengan datang tepat waktu, meninggalkan sekolah sesuai dengan jam yang telah ditentukan, dan memasuki kelas tepat waktu, hendaknya kedisiplinan yang sudah sangat baik ini dapat memberikan contoh yang baik untuk peserta didiknya.

\section{e. Kedisiplinan Dalam Sikap dan Tingkah Laku}

Pada kedisiplinan dalam melaksanakan tugas tata tertib dengan baik rata-rata nilai yang diperoleh semua guru adalah 3,2 dengan kriteria cukup dimana pada kedisiplinan dalam sikap dan tingkah laku nilai rata-rata paling tinggi 5,0 diperoleh UK, MA dan CSD dengan kritor yang diperoleh adalah 5 , sedangkan nilai rata-rata paling rendah 2,0 diperoleh guru MJ, RF, SM dan SR dengan kriteria kurang dengan skor 2.

Berdasarkan pada kedisiplinan sikap dan tingkah laku rata-rata hasil yang diperoleh semua guru pada lembar observasi adalah 3,2 dari keseluruhan skor yang diterima dengan kriteria cukup dimaksudkan rata-rata kedisiplinan guru sudah melaksanakan dengan baik namun ada beberapa item pernyataan yang belum berjalan dengan baik seperti pada item pernyataan nomor 29, 31, 34 dan 35 dimana item pernyataan tersebut belum terlaksana dengan baik.

Di mana setiap guru pada observasi yang dilakukan sudah melakukan kedisiplinan sikap dan tingkah laku dengan baik, seperti menggunakan handphone saat kegiatan belajar mengajar, guru hendaknya tidak menggunkan handphone karna dapat mengganggu kegiatan belajar mengajar dikelas. Ketika guru mempunyai permasalahan pribadi hendaknya guru tidak membawa persoalan tersebut saat mengajar sehingga pelaksanaan kegiatan belajar mengajar di sekolah tidak terganggu.

\section{Pembahasan}

Berdasarkan hasil penelitian dan deskripsi penelitian di atas pelaksanaan kedisiplinan guru PAUD di Gugus Asoka Kecamatan Sungai Serut Kota Bengkulu, secara keseluruhan rata-rata hasil akhir yaitu 4,5 dalam kriteria baik karena pada pelaksanaannya semua guru sudah melaksanakan kedisiplinan yang sesuai dengan peraturan yang ada di sekolah masing-masing dengan rata-rata baik namun masih ada beberapa kedisiplinan guru yang masih perlu diperhatikan lagi dilihat dari pelaksanaan item pernyataan yang sudah diisi sesuai dengan pelaksanaannya.

Dalam pelaksanaannya sesuai dengan identifikasi masalah di mana pelaksanaan kedisiplinan guru dapat berpengaruh juga terhadap kedisiplinan pada peserta didiknya. Hal ini sesuai dengan pendapat Mulyasa (2009: 122) mengatakan bahwa dalam pendidikan, mendisiplinkan anak harus dimulai dari pribadi guru yang disiplin, kita tidak bisa berharap banyak akan terbentuknya anak yang disiplin dari 
pribadi yang kurang disiplin. Oleh karena itu membina anak usia dini harus dimulai dari pribadi guru yang disiplin. Semakin baik disiplin guru maka memberikan pengaruh terhadap disiplin anak didiknya. dalam

pelaksanaan kedisiplinan guru PAUD, terdapat beberapa kedisiplinan yang menurut peneliti memiliki kelemahan dan perlu diperhatikan. Pada pelaksanaan kedisiplinan sikap dan tingkah laku berada dalam nilai terendah sebaiknya dapat diperhatikan lagi agar dapat memberikan contoh yang baik untuk anak didiknya.

Kemudian guru dengan nilai terendah juga perlu diperhatikan untuk lebih menigkatkan lagi pelaksanaan kedisiplinan yang sudah menjadi aturan sekolah agar peserta didik mencontoh cerminan sikap yang baik dari seorang gurunya. Hal ini sejalan dengan pendapat Sastrohadiwiryo (2002: 90) bahwa faktor pendukung dominan bagi kedisiplinan guru berasal dari guru sendiri. Faktor-faktor tersebut yaitu kompetensi, motivasi, kreativitas dan produktifitas guru, pendidikan serta karakter guru.

Berdasarkan hasil di atas, adapun alasan penting dalam pelaksanaan kedisiplinan guru perlu untuk diterapkan oleh setiap guru di mana seorang guru yang professional harus melaksanakan kedisiplinan sesuai dengan tata tertib yang ada di sekolah dan dimulai dari diri guru sendiri agar dapat menajalankan perannya sebagai contoh untuk anak didiknya.

$\mathrm{Hal}$ ini sejalan dengan pendapat Mulyasa (2013: 188) yang mengatakan bahwa berdisiplin mengandung makna bahwa guru menyadari, memahami dan mematuhi berbagai peraturan dan tata tertib secara konsisten dan professional karena mereka bertugas untuk mendisiplinkan para peserta didiknya, oleh karenanya dalam menanamkan disiplin guru harus memulai dari dirinya sendiri dalam berbagai tindakan dan perilakunya.

\section{KESIMPULAN}

Berdasarkan hasil penelitian yang dilakukan di Gugus Asoka Kecamatan Sungai Serut Kota Bengkulu secara keseluruhan hasil akhir yang diperoleh adalah dalam kriteria baik. Apabila dilihat dari kedisiplinan dalam melaksanakan tugas tata tertib, kedisiplinan dalam melayani peserta didik, kedisiplinan suasana kerja dan disiplin waktu memperoleh kriteria sangat baik dalam pelaksanaannya. Pada kedisiplinan dalam sikap dan tingkah laku masih dalam kriteria cukup dilihat dalam pelaksanaannya.

\section{Saran}

Berdasarkan hasil penelitian yang telah dilakukan. Maka saran yang dapat diberikan pada penelitian ini adalah bagi kepala sekolah hendaknya selalu senantiasa memberikan dorongan dan motivasi pada guru untuk senantiasa memperlihatkan dan mempraktikkan kedisiplinan yang lebih baik lagi. Karena saat penelitian masih berlangsung ada beberapa guru yang masih belum bisa berdisplin dalam berbagai hal.

Sedangkan bagi saran yang bisa diberikan kepada guru adalah diharapkan dapat dipertahankan, dan untuk yang belum bagus dapat ditingkatkan lagi.

Sedangkan bagi penelitian selanjutnya, dapat disarankan selain mendeskripsikan kedisiplinan, hal lain yang bisa diobservasi adalah manajemen perilaku siswa dan guru. Bagaimana siswa seharusnya bersikap mulia selama berada di sekolah.

\section{DAFTAR PUSTAKA}

Agustriana, N. (2019). PENGARUH METODE EDUTAINMENT DAN IDENTITAS DIRI TERHADAP KETERAMPILAN SOSIAL ANAK. Al-Fitrah, 1(2), 216-228. Retrieved from http://ejournal.iainbengkulu.ac.id/inde x.php/alfitrah/article/view/1517 
Anggraini. (2017). Upaya Guru DalamMeningkatkan Kompetensi Pedagogik Di SMK Negeri 3 Buduran Kabupaten Sidoarjo. Kajian Moral dan Kewarganegaraan

Aqib, Z., dkk. (2009). Penelitian Tindakan Kelas. Bandung: Yrama Widya

Arikunto, S. (2010). Prosedur Penelitian Suatu Pendekatan Praktik. Jakarta: PT Rineka Cipta

Aritonang. (2005). Disiplin Kerja Guru. Jogjakarta: Ar Ruzz Media

Asmani, J. M. (2009). 7 kompetensi Guru Menyenangkan dan Profesional. Jogjakarta: Power books (IHDINA)

Barnawi, A. M. (2014). Instrument Pembinaan, Peningkatan \& Penilaian Kinerja Guru Profesional. Jogjakarta: Ar Ruzz MediaBinti,

Daryanto. (2013). Standard Kompetensi dan Penilaian Kerja Guru Profesional.Yogyakarta: Gava Media.

Djamarah, S.B. (2005). Guru dan Anak Didik Dalam Interaksi Edukatif. Jakarta:PT Rineka Cipta.

Djamarah, S. B. (2010). Guru dan Anak Didik Dalam Interaksi Edukatif. Jakarta: Rineka Cipta

Drajat. (2014). Etika Profesi Guru. Bandung: Aflabeta

Furqon, H. (2015). Pendidikan Karakter: Membangun Peradapan Bangsa, Surakarta: Yuma Pressindo

Hurlock, \& Elizabeth. (1990). Psikologi Perkembangan Anak. Jakarta: PT Erlangga
Idris, M., \& Sandra, M. (2010). Menjadi Guru Unggul. Jogjakarta: Ar-Ruzz Media Group

Imran, A. (2011). Manajemen Peserta Didik Berbasis Sekolah. Jakarta: Bumi Aksara

Jannah, L. A. (2013). Kesalahan-kesalahan guru PAUD yang sering dianggap sepeleh. Jogjakarta: DIVA Press

Maunah. (2009). Landasan Pendidikan. Yogyakarta: Teras

Mulyasa. (2005). Menjadi Guru Profesional, Menciptakan Pembelajaran Kreatif dan Menyenangkan. Bandung: Rosdakarya

Mulyasa. (2006). Menjadi Guru Profesional, Menciptakan Pembelajaran Kreatif dan Menyenangkan. Bandung: PT Remaja Rosdakarya

Mulyasa. (2009). Standar Kompetensi dan Sertifikasi Guru. Bandung: PT Remaja Rosdakarya

Nashir, A. (2016). Pengaruh Kedisiplinan Guru Terhadap Prestasi Belajar. Universitas Muhammadiyah Makassar

Ngainun, N. (2012). Character Building. Jogjakarta : AR-RUZZ MEDIA

Nopriyadi, A. (2016). Pendidikan Kedisiplinan di Taman Kanak-kanak Dharma Bakti Kabupaten Sleman. Universitas Negeri Yogyakarta

Rahman, M. A. (2013). Kesalahan-kesalahan guru saat mengajar. Jogjakarta: Laksana

Rimang. (2011). Meraih Predikat Guru dan Dosen Paripurna. Bandung: Alfabeta.

Rusyan, A. T., dkk. (2006). Pendekatan dalam Proses Belajar Mengajar. Bandung: Remaja Karya 
Sastrohadiwiryo. (2002). Manajemen Tenaga Kerja Indonesia, PT. Bumi Aksara, Jakarta.

Sugiyono. (2006). Metode Penelitian Kuantitatif, kualitatif, Dan $R \& D$. Bandung: ALFABETA

Sugiyono. (2010). Metode Penelitian Pendidikan. Bandung: ALFABETA
Sujiono, Y. N. (2011). Konsep Dasar Pendidikan Anak Usia Dini. Jakarta: PT Indeks

Yoesana. (2013). Hubungan antara Motivasi Kerja dengan Disiplin Kerja Pegawai. Jakarta : Gramedia Pustaka 